environment by enterprises, organizations and establishments a 20514, 0 million UAH (without VAT) were spent, that comparatively $11 \%$ more than in 2016. Thus, due to a money state and local budgets it was mastered only 7,0 \% of capital investments and it is carried out 3,3\% of current outlays, and the personal funds of enterprises and organizations were the basic sourcing of charges on the guard of environment, as well as in previous years, accordingly $59,1 \%$ and $96,6 \%$.

One of the methods of decision of the problem of negative ecological processes there is adjusting of ecological constituents by the use of levers and instruments of the tax system.

The world experience plays a large role in the development of ecological insurance, and it shows that ecological insurance is a necessary attribute of market economy, as technogenic accidents and catastrophes lie down weight on the economy of any country, causing considerable financial losses.

For the increase of efficiency of realization of present and new types of insurance in the field of nature management and guard of environment, and also providing of financial firmness of insurance operations, it is necessary to create the special professional associations, which will provide co-ordination of activity of insurance companies which will be able to carry out ecological insurance, and also build the effective system of ecological re-insurance. Elimination of legislative, methodological and organizational problems will enable, despite recurring crisis phenomena in the domestic economy, to create a civilized market of environmental insurance, which will contribute to the development of the domestic market of environmental services.

Key words: ecological insurance, ecological taxation, environmental protection, natural resources, ecological situation, ecological risk, environmental costs

UDC 504.03

DOI 10.31395/2415-8240-2019-94-2-58-69

\title{
STRATEGIC MANAGEMENT DIRECTIONS OF SOLID DOMESTIC WASTE SPHERE IN THE POLTAVA REGION
}

\author{
P. V. Pisarenko, Doctor of Agricultural Sciences \\ M. S. Samojlik, Doctor of Economics \\ O. Yu. Dychenko, Candidate of Agricultural Sciences \\ Poltava State Agrarian Academy, Poltava, Ukraine
}

Розроблено оптимізацію моделі розвитку у сфері управління твердими побутовими відходами в регіоні, спрямованої на збалансування економічних та екологічних критеріїв. Також були визначені напрями розвитку для поводження з твердими побутовими відходами в контексті реалізації сочіально-економічних та екологічних стратегій та рекомендацій щодо поліпшення фінансової та економічної підтримки.

Ключові слова: тверді побутові відходи, сфера управління відходами, регіон, стратегія розвитку, фінансова та економічна підтримка, збалансований розвиток. 
Statement of the problem. One of the conditions for sustainable territorial development is a socio-ecological-economic balance in the region, which presents such a state of regional systems that provides economic growth, social stability and ecological safety in the region. Violation of this balance leads to the emergence of losses having different characteristic features: ecological, economic and social. An essential element of socio-ecological-economic balance in the region is effective functioning of municipal solid waste (MSW) management sphere.

The problem of achieving sustainable development in the region expands the sphere of human impact on the environment and intensifies the use of natural resource base, which inevitably brings the problem of rational use of secondary resources to the fore. The region becomes a self-active economic agent, an active subject of competitive relations in national and global economy. In a deeper sense, as V. I. Vernadski noted in his studies, the solution of this problem requires creation of a new international order aimed at ensuring coordinated actions of the entire world community to avert environmental disaster, that is the transition to the noosphere development as intelligently managed co-development of a human being, society and nature, in which the satisfaction of vital needs of the population is made without prejudice for nature and future generations [1].

Today MSW management sphere in the region does not have systemic features, most likely it is a set of related but non-effective elements. Exactly under these conditions the task of transformation of "a set of elements" into a system becomes important through the development of MSW management system, covering all aspects of solid waste management: social, economic, technological, environmental and legal and their optimization. In this regard the region can and should become the backbone "vehicle" of the state policy in this area and provide a purposeful wide range decision of the problems related to waste handling.

The analysis of recent studies and publications discussing the problem. It is to be noted that effective waste management problem has been solved to some extent in developed countries, in the first place in Europe. Though for example, "garbage crisis" of 2007-2008 in Naples showed that Western experts having great experience and scientific knowledge in the field of solid waste management cannot assert that the problem is completely solved [2]. As for Ukraine, primarily the sphere of waste management is in a state that has been inherited from the planned economy of the former Soviet Union. In recent years a large number of works devoted to this problem has appeared in Ukraine, including the works by A. I. Bondar [3], V. Ye. Baranovsky, V. L. Pilyushenko [4], O. V. Moroz, A. O. Sventyh [5], V. S. Mishchenko, G. P. Vygovsky [6] and others. However, despite the significant scientific principles established by these and other scholars, their attention is focused mainly on the technical and technological aspects of the 
problem. At the same time there is lack of scientifically based methods and mechanisms of effective management in this field. Poorly substantiated here is also economic leverage. Besides the issues focused on getting the desired effect from the use of the potential waste management sphere, as a part of the total potential of the region's economy and as a result of cumulative actions of the participants of the wastes management sphere, have not yet received proper consideration up till now. That is, there is a need for comprehensive theoretical elaboration and practical improvement of MSW managing based on the parameters and the criteria of the region sustainable development in terms of spreading globalization.

Research methodology. Modern society characterized by contradiction of two interrelated processes - economic growth and limited assimilation properties biosphere. It can be noted that the previous conceptual basis of the economy and development of society exhausted, and the use of traditional methods to achieve the objectives unacceptable in solving new problems environmental protection, which requires a paradigm shift in social development in eco-oriented, resulting in has become harmonious, environmentally sound socio-economic development and conservation of environmental quality and natural resources. In this context methodological research on environmental safety should be multidisciplinary and include elements of the theory that define the purpose of applied research: systemic, synergistic, strategic, targeted, value and functional approaches; dialectical and metaphysical methods of learning, the cyclical nature of nature and society.

Task statement. It is necessary to work out the optimization model of waste solid management aimed at balancing of the two mutually contradictory criteria: economic damage for environmental pollution and total expenses for the functioning of MSW handling sphere. The model will create the basis for determination of strategic development directions in the given sphere within realization of socio-economic and ecological strategy of regional development.

Results of investigation. In the Poltava region the growth trend of MSW formation since 2000 has been observed, its composition, physical and chemical characteristics being diversified.

The annual MSW formation per capita has also increased (from 0.25 ton per a person a year in 1998 to 0.42 ton per a person a year in 2017). This is a common trend in Ukraine. Thus, the volume of the formed MSW in 2000 was 0.99 million $\mathrm{m}^{3}$, in 2011 it was 1.1 million $\mathrm{m}^{3}$, in 2017 it became 1.6 million $\mathrm{m}^{3}$ (1.6 times more than in 2000). A considerable part of MSW (34.11\%) is formed in Poltava and Kremenchug. Coverage of the Poltava region population by collecting and removing waste services is $60 \%$ on the average, for urban population it being $90 \%$ and for rural $-25 \%$ [7]. 
Comparing with 1998 the content of polymer waste, glass, paper and cardboard waste in MSW has considerably increased. The reason for this is, in the first place, the increase of packing material and its diversity. At the same time the volume of utilization of MSW valuable fractions does not exceed 3\% on the average. So, in 2017 the amount of collected waste paper was $9697.97 \mathrm{~m}^{3}$, of polymers $-8829.03 \mathrm{~m}^{3}$, of glass $-2734.15 \mathrm{~m}^{3}$. In fact, the collection of resource valuable fractions in the area of MSW collection is currently done in Myrgorod, the system is implemented in Kremenchug, Horol, Lubny. Therefore, most of the resource valuable materials that make MSW are transported to the landfills and dumps and are sorted partially into separate groups. The amount of resource valuable components is not controlled. Sorting out waste is not centralized and is done by hand with the assistance of other physical persons - enterpreneurs on a contractual basis. An important problem in this sphere is the off-gauge waste that cause the formation of unauthorized dumps [8].

Handling the collected MSW in the Poltava region includes mainly liquidation method now. According to the State Administration of Environmental Protection of the 1.01.2017 in the Poltava region there were 377 authorized landfills and MSW dumps with a total area of 460.2 hectars, of which 90 have been certified and calculated. Today about $60 \%$ of landfills do not meet the standards of environmental safety and more than $18.5 \%$ are overloaded. The area of illegal dumps has also increased significantly. In 2008 the dumps were found with the total area of 18 hectars, in 2009 - 298 landfills with the area of 13.7 hectars, in 2017 - 411 dumps with the area of 60.2 hectars.

The carried out research in MSW handling sphere allows to distinguish the major problems in the field of waste handling in the Poltava region. They are: particular constant increase in waste formation in the region, low utilization level of MSW landfills and lack of correspondence of the majority of them to environmental health and safety standards, situations regarding waste handling in disorganized storage space is far from being satisfactory. On the whole the situation in the Poltava region in waste handling sphere is complex, it results in the loss of great amount of secondary materials and the shortfall of revenue from their utilization, the need for a permanent allocation of considerable amount of financial resources for building new waste grounds. The maintenance of the existing landfills and dumps in most cases create ecologically hazardous conditions in the areas of landfill.

The studies of current trends and the problems of solid waste handling in the Poltava region testify to the necessity of working out the strategy of waste handling development sphere accounting the interests of all stakeholders of this process [9]. According by the optimization model of waste solid handling development has 
been offered, it is aimed at balancing the two opposite criteria: economic damage from environmental pollution (D) and the total operation cost of the sphere (V):

$V=\sum_{t=1}^{T}\left[\frac{1}{(1+i)^{t}} \cdot\left(A_{t} \cdot X_{t}+B_{t} \cdot Y_{t}+C_{t} \cdot Z_{t}+E_{t}+F_{t}\right)\right]$,

$\underset{(1)}{D=} \sum_{t=1}^{T}\left(\left(\left(\gamma \sum_{m=1}^{M} E R_{m}^{A} \cdot H_{\text {factor }_{m}}^{A}\right)+\left(\alpha \sum_{n=1}^{N} E R_{n}^{W} \cdot H_{\text {factor }_{n}}{ }^{W}\right)\right) \cdot X_{t}+\left(\left(\gamma \sum_{m=1}^{M} E L_{m}^{A} \cdot H_{\text {factor }_{m}}^{A}\right)+\left(\alpha \sum_{n=1}^{N} E L_{n}^{W} \cdot H_{\text {factor }_{n}}^{W}\right)\right) \cdot Y_{t}\right)$,

where $i$ - the discount rate;

$t$ - functioning periods of MSW handling sphere per year;

$A$ - processing costs, excluding profit from the sale of resource fractions (hryvnias/ton);

$B$ - the cost of collecting and transportation of MSW (hryvnias/ton);

$C$-the disposal cost of MSW burial (hryvnias/ton);

$X-\mathrm{MSW}$ mass that goes to recycling (ton);

$Y$ - MSW mass that is transported to the landfill (ton);

$Z$ - total MSW amount that is removed, and the residue from recycling (ton);

$E, F-$ the cost of putting the processing plant (station), waste ground into operation (hryvnias);

$E R^{A}, E R^{w}$-emission of pollutant substances into water or the atmosphere in compliance with "recycling" technology (ton);

$E L^{A}, E L^{w}$ - emission of pollutant substances into water or the atmosphere in compliance with "burrying" technology (ton);

$\mathrm{H}_{\text {factor }}{ }^{\mathrm{A}}, \mathrm{H}_{\text {factor }}{ }^{\mathrm{W}}$ - coefficients of pollutants relative harmfulness that enter the atmosphere and water;

$\gamma, \alpha-$ constant values that are determined considering inflation rate (hryvnias/ton);

$m, n$ - the amount of pollutants entering the atmosphere and water.

On the basis of the proposed model the optimal ratio of ecological and economic criteria for the development of waste management in the Poltava region (Fig. 1) has been determined. The development of MSW management sphere should be aimed at resolving the priority issues of: providing environmentally safe MSW management at maximizing recycling and market development of recyclable materials, minimizing waste forming. Solving these problems in the region should be performed in accordance with the main directions that are proposed to be carry out in three phases (Figure 1). 


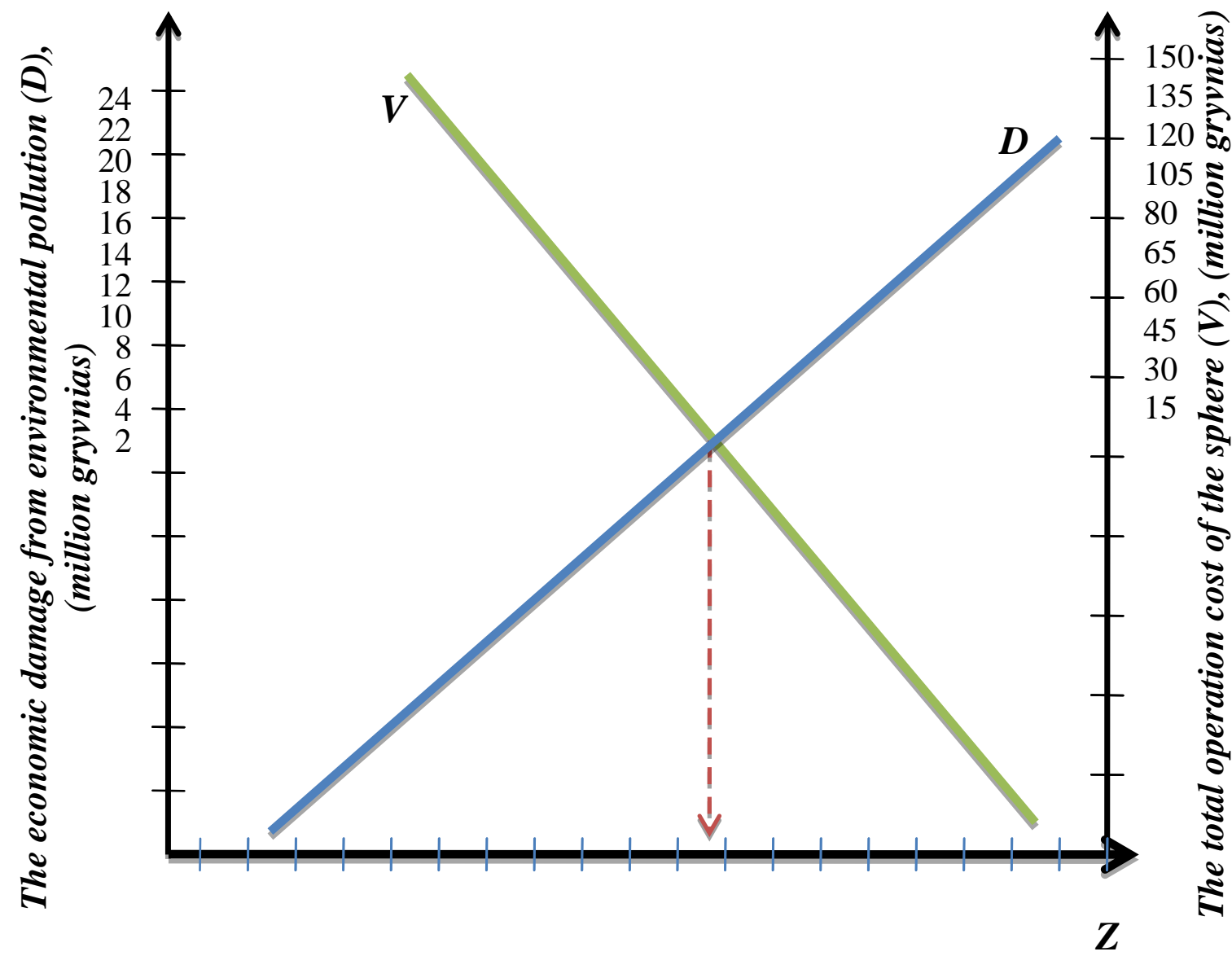

Volume of MSW removal, \% from the general volume

Fig. 1 - Optimal ratio of development criteria in MSW sphere in the Poltava region (it is made authors)

According to the defined development directions of MSW handling sphere the urgent problem remains this: a wide application of financial and economic provision measures. But the vector of using these measures should have innovational character for creating powerful production potential from secondary raw materials; ecological safety and social growth must be promoted. Otherwise the financial resources coming into the sphere of waste management will compensate losses from irrational management in this sphere and will support uncompetitive model of production organisation. Considering the demands to local development policy of MSW handling sphere, introducing the system of priority measures of financial and economic supply of optimal functioning and development of the sphere as well as the Resolution of EU Council "The Strategy of the European Union in Waste Management" it is necessary to strive for realization of tactic goals: minimization of MSW formation and their highest possible utilization and there safe removal (Fig. 3). 


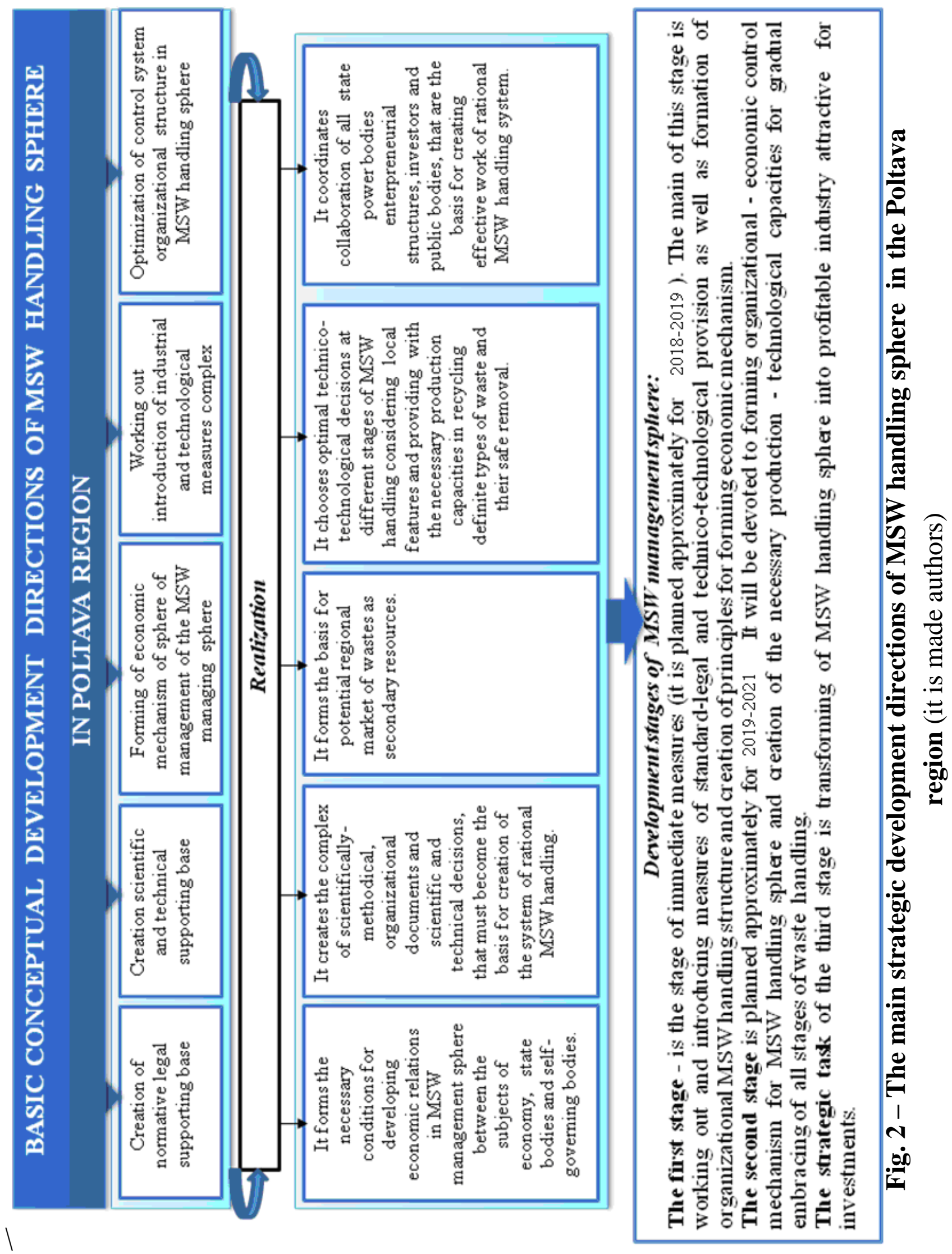

The mentioned measures will have to be realized in 3 stages: stage I immediate measures aimed at intensifying the process, the II stage - medium measures aimed at taking into account the existing conditions, the III stage - long- 
term measures aimed at preserving the favorable conditions in certain target areas.

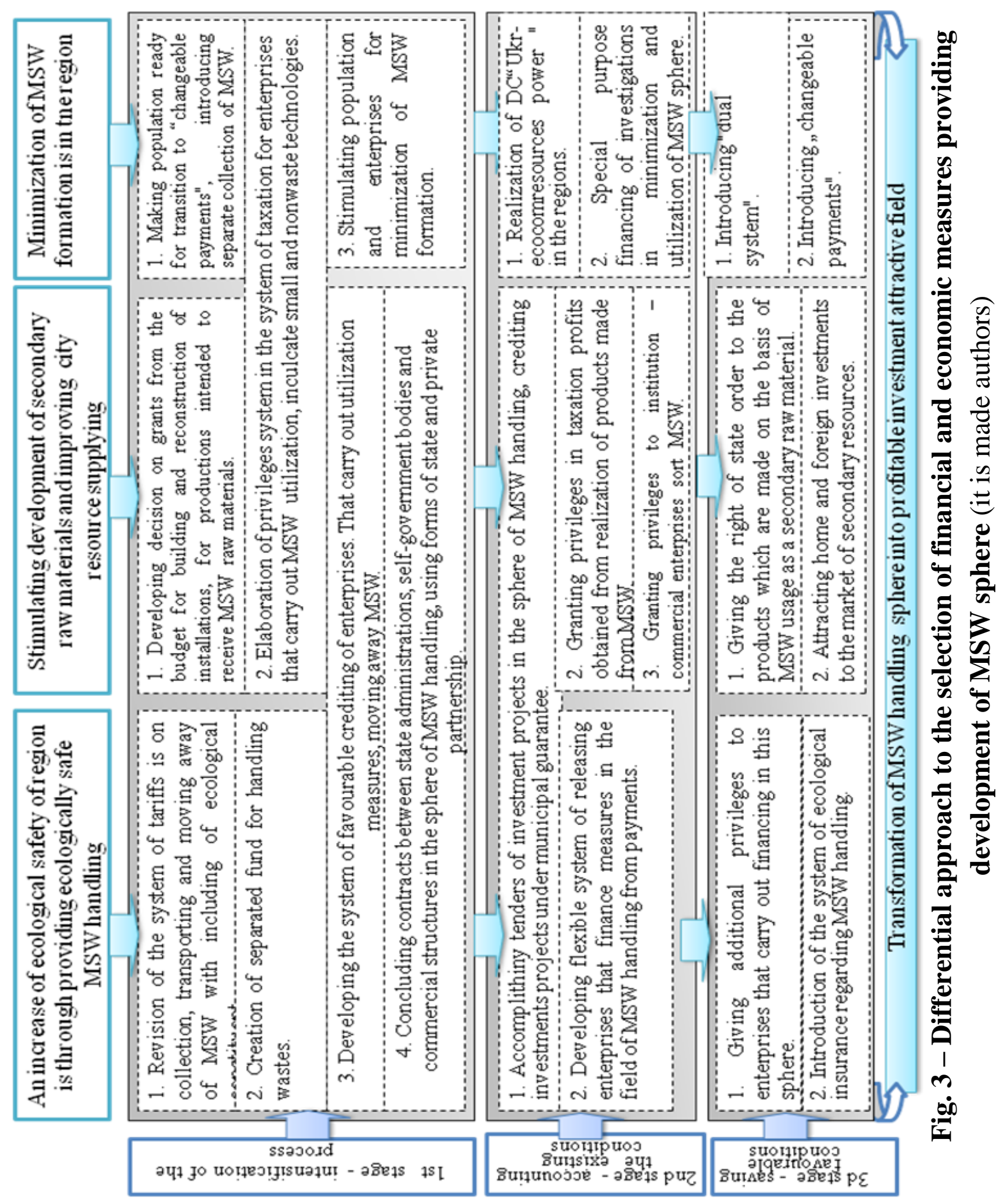

Conclusion. The development strategy of MSW sphere allows to the formation of an effective integrated waste management system that will enable achieving the following results: creating legal, scientific and technical basis for rational and safe waste management, developing economic instruments aimed at 
forming and developing waste market as secondary resources; improving of organizational infrastructure for sustainable waste management; introduction a single system of accounting, control and management of MSW streams and establishing a system for monitoring ecological condition for the disposal places of solid waste; providing environmentally safe disposal of solid waste and creating trends for reducing "end wastes", which are transported to the landfill; reducing unauthorized removal of solid waste and economic loss for the solid waste pollution; minimization of MSW formation; increasing waste utilization coefficient and investments in this given sphere, introducing separate collection system of solid waste; construction of waste sorting station for development of second resources market; providing population with services for collecting waste and with technical means of removal of solid waste; creation of capacities for utilization of organic waste at composting plants.

\section{Література}

1. Вернадский of В.И. Biosphere and noosphere. Москва : Айриспресс, 2004. $576 \mathrm{p}$.

2. The Global Partnership for Environment and Development. A Guide to Agenda 21. Geneva: UNCED, 2006. 116 p.

3. Бондар О. I. та ін. Управління відходами: вітчизняний та зарубіжний досвід: посібник. за ред. О.І. Бондаря. Київ : Айва Плюс Лтд, 2008. $196 \mathrm{c}$.

4. Теоретико-методичні і практичні засади управління твердими побутовими відходами високо урбанізованих промислових регіонів ${ }^{\wedge}$ монографія / В.Л. Пілюшенко та ін.; за ред. В. Л. Пілюшенко. Донецьк: Технопак, ДонДУУ, 2009. 338 с.

5. Мороз О.В., Свентух А. О., Свентух О. Т.. Економічні аспекти вирішення екологічних проблем утилізації твердих побутових відходів. Вінниця : УНІВЕРСУМ, 2003. $110 \mathrm{c}$.

6. Міщенко В. С. Виговська Г. П.. Організаційно-економічний механізм поводження з відходами в Україні та шляхи його вдосконалення. Київ : Наукова думка, 2009. 294 с.

7. Поводження 3 відходами Полтавщини / Ю.С. Голік та ін. Полтава : Полтавський літератор, 2009. 291 с.

8. Регіональна програма охорони довкілля, раціонального використання природних ресурсів та забезпечення екологічної безпеки 3 урахуванням регіональних пріоритетів Полтавської області / В.О. Онищенко та ін. Полтава: Полтавський літератор, 2012. 164 с.

9. Онищенко С.В., Самойлік М.С. Еколого-економічна оцінка 
забруднення навколишнього середовища в системі екологічно безпечного розвитку регіонів України: монографія. Полтава: ПолтНТУ, 2012. 269 с.

\section{References}

1. Vernadsky V.I. (2004). Biosphere and noosphere. M.: Iris-press, 2004. $576 \mathrm{p}$.

2. The Global Partnership for Environment and Development. A Guide to Agenda 21. Geneva: UNCED, 2006. 116 p.

3. Bondar O.I. and other. (2008). Waste management: domestic and foreign experience. K .: Iva Plus Ltd, 2008. 196 p.

4. Pilushenko V.L. and other. (2009). Theoretical-methodical and practical ambush management with solid problems with high-profile industrial regions. Donetsk: Technopak, DonDUU, 2009. 338 p.

5. Moroz O.V, Sventukh A.O., Svenktukh O.T. (2003). Economical aspects and environmental problems of utilization of solid pobutovyhs. Vinnitsa: UNIVERSUM, 2003. $110 \mathrm{p}$.

6. Mishchenko V.S., Vygovskaya G.P. (2009). Organizational and economic mechanism of waste management in Ukraine and ways of its improvement. K : Scientific thought, 2009. $294 \mathrm{p}$.

7. Golik Yu.S. (2009). Handling of waste from Poltava region. Poltava: Poltava Literature, 2009. $291 \mathrm{p}$.

8. Onishchenko V.O. and others. (2012). Regional program of environmental protection, rational use of natural resources and ensuring environmental safety taking into account regional priorities of the Poltava region. Poltava: Poltava Literature, 2012. 164 p.

9. Onischenko S.V., Samoylik M.S. (2012). Ecological and economic assessment of environmental pollution in the system of environmentally safe development of regions of Ukraine: monograph. Poltava: PoltNTU, 2012. 269 p.

\section{Аннотация}

Писаренко П. В., Самойлик М. С., Дяченко О. Ю.

Стратегические направления управления сфере обращения с твердыми бытовыми отходами полтавском регионе

Проблема обрашения с твердыми отходами, повышение эффективности использования природно-экономического потенциала территории является одной из приоритетных для каждого региона Украины. В статье разработаны оптимизачионные модели развития сферы обращения с твердыми бытовыми отходами региона, которая направлена на сбалансирование экономических и экологических критериев.

Полученные результаты исследования позволили сформировать стратегические направления развития сферы обращения с твердыми бытовыми отходами в контексте реализаџии соџиально-экономической и экологической стратегии и даны рекомендаџии по 
совершенствованию ее финансово-экономического обеспечения. Практическая значимость работы заключается в оптимизации стратегии обращения с твердыми бытовыми отходами в регионе, реализация которой позволит: формирование эффективной комплексной системь управления ТБО, которая даст возможность достижения следующих результатов: создание нормативно-правовой и научнотехнической базы рачионального и безопасного обращения с ТБО; разработку системь экономических рычагов, направленных на формирование и развитие рынка отходов как вторичных ресурсов; совершенствование организационной инфраструктуры для рачионального обращения с ТБО; внедрение единой системь учета, контроля и управления потоками ТБО и настройка системы мониторинга за экологическим состоянием мест удаления отходов; обеспечение экологически безопасного удаления ТБО и создание тенденций по уменьшению объемов "конечных отходов", которые вывозятся на свалку; уменьшение несанкиионированного удаления ТБО и экономического ущерба за загрязнение окружающей среды ТБО; минимизаџию образования отходов; увеличение коэффициента утилизации отходов и увеличение инвестищий в данную сферу, внедрение системь раздельного сбора ТБО; строительство мусоросортировочной станции и развитие рынка вторресурсов; обеспечение населения услугами по сбором ТБО и техническими средствами вывоз ТБО; создание мощностей для утилизации органических отходов в компостных предприятиях.

\section{Annotation}

\section{Pysarenko P., Samojlik M., Dychenko O.}

\section{Strategic management directions of solid domestic waste sphere in the poltava region}

A problem of providing of municipal solid waste management sphere, increase of efficiency of the naturally-economic potential use of territory is one of priority for every region of Ukraine. Optimization of development model in municipal solid waste management sphere in the region aimed at balancing economic and environmental criteria has been developed.

Have also been determined development directions for handling municipal solid waste in the context of realization of socio-economic and environmental strategies and recommendations regarding improvement in financial and economic support. The methodological basis of the study were the results of basic and applied research in the field of physical economy, ecological economics, of the concept of sustainable development.

The development strategy of municipal solid waste sphere allows to the formation of an effective integrated waste management system that will enable achieving the following results: creating legal, scientific and technical basis for rational and safe waste management, developing economic instruments aimed at forming and developing waste market as secondary resources; improving of organizational infrastructure for sustainable waste management; introduction a single system of accounting, control and management of municipal solid waste streams and establishing a system for monitoring ecological condition for the disposal places of solid waste; providing environmentally safe disposal of solid waste and creating trends for reducing "end wastes", which are transported to the landfill; reducing unauthorized removal of solid waste and economic loss for the solid waste pollution; minimization of municipal solid waste formation; increasing waste utilization coefficient and investments in this given sphere, introducing separate collection system of solid waste; construction of waste sorting station for development of second resources market; providing population with services for collecting waste and with 
technical means of removal of solid waste; creation of capacities for utilization of organic waste at composting plants.

The results of research allowed to form conceptual principles of providing of municipal solid waste management sphere in the regions of Ukraine, oriented to the increase of efficiency of territory naturally-economic potential use on the basis of solid wastes capitalization and minimization of their negative influence.

Key words: municipal solid wastes, sphere of waste management, region, strategy of development, financial and economic support, balanced development.

УДК 368 (477)

DOI 10.31395/2415-8240-2019-94-2-69-85

\title{
РОЗВИТОК УКРАЇНСЬКОГО РИНКУ СТРАХОВИХ ПОСЛУГ В КОНТЕКСТІ ЗАБЕЗПЕЧЕННЯ ЕКОНОМІЧНОЇ БЕЗПЕКИ КРАЇНИ
}

\author{
О. Т. Прокопчук, кандидат економічних наук \\ Уманський національний університет садівництва
}

У статті проведено оцінку рівня фінансової безпеки украӥнського ринку страхових послуг, як ключового компонента економічної безпеки держави, що визначається низкою показників - індикаторів та здійснено їх співставлення з пороговими значеннями. Досліджено особливості функиіонування аналізованого ринку в иілому, та в розрізі його галузевої класифікації (довгострокового страхування - страхування життя та загальних (ризикових) видів страхування).

Ключові слова: ринок страхових послуг, економічна безпека, фінансова безпека, фінансова безпека страхового ринку, ключові показники страхової діяльності, індикатори фінансової безпеки

Постановка проблеми. Становлення і подальший розвиток ринкової системи господарювання зумовлюють необхідність формування досконалого ринку страхових послуг, як особливої частини ринку фінансових послуг, в умовах соціально орієнтованої економіки та концепції сталого розвитку, в основу якої покладено виважене та збалансоване поєднання кількох складових, зокрема економічної активності, інтересів соціального характеру, а також діяльності направленої на охорону довкілля. Водночас, український ринок страхових послуг все ще знаходиться на стадії становлення, що в окремих ситуаціях не дозволяє розглядати, а відтак і застосовувати його як дієвий інструмент реалізації політики держави.

Аналіз останніх досліджень і публікацій. Різні аспекти пов'язані 3 